USAWC STRATEGY RESEARCH PROJECT

\title{
ISLAMIC FASCISM: A REAL THREAT
}

\author{
by \\ Commander Andrew C.Escriva \\ United States Navy
}

\author{
Mr. Scott Forster \\ Project Adviser
}

This SRP is submitted in partial fulfillment of the requirements of the Master of Strategic Studies Degree. The U.S. Army War College is accredited by the Commission on Higher Education of the Middle States Association of Colleges and Schools, 3624 Market Street, Philadelphia, PA 19104, (215) 662-5606. The Commission on Higher Education is an institutional accrediting agency recognized by the U.S. Secretary of Education and the Council for Higher Education Accreditation.

The views expressed in this student academic research paper are those of the author and do not reflect the official policy or position of the Department of the Army, Department of Defense, or the U.S. Government. 


\section{Report Documentation Page}

Form Approved

OMB No. 0704-0188

Public reporting burden for the collection of information is estimated to average 1 hour per response, including the time for reviewing instructions, searching existing data sources, gathering and maintaining the data needed, and completing and reviewing the collection of information. Send comments regarding this burden estimate or any other aspect of this collection of information,

including suggestions for reducing this burden, to Washington Headquarters Services, Directorate for Information Operations and Reports, 1215 Jefferson Davis Highway, Suite 1204, Arlington

VA 22202-4302. Respondents should be aware that notwithstanding any other provision of law, no person shall be subject to a penalty for failing to comply with a collection of information if it

does not display a currently valid OMB control number.

1. REPORT DATE

30 MAR 2007

4. TITLE AND SUBTITLE

Islamic Fascism A Real Threat

6. $\operatorname{AUTHOR}(\mathrm{S})$

Andrew Escriva

7. PERFORMING ORGANIZATION NAME(S) AND ADDRESS(ES)

U.S. Army War College,Carlisle Barracks,Carlisle,PA,17013-5050

9. SPONSORING/MONITORING AGENCY NAME(S) AND ADDRESS(ES)

2. REPORT TYPE

Strategy Research Project
3. DATES COVERED

00-00-2006 to 00-00-2007 5a. CONTRACT NUMBER

5b. GRANT NUMBER

5c. PROGRAM ELEMENT NUMBER

5d. PROJECT NUMBER

5e. TASK NUMBER

5f. WORK UNIT NUMBER

8. PERFORMING ORGANIZATION

REPORT NUMBER

10. SPONSOR/MONITOR'S ACRONYM(S)

11. SPONSOR/MONITOR'S REPORT NUMBER(S)

12. DISTRIBUTION/AVAILABILITY STATEMENT

Approved for public release; distribution unlimited

13. SUPPLEMENTARY NOTES

14. ABSTRACT

See attached.

15. SUBJECT TERMS

16. SECURITY CLASSIFICATION OF:

a. REPORT

unclassified b. ABSTRACT

unclassified c. THIS PAGE unclassified
17. LIMITATION OF ABSTRACT

\begin{tabular}{|l|l}
$\begin{array}{l}\text { 18. NUMBER } \\
\text { OF PAGES }\end{array}$ & 19a. NAME OF \\
$\mathbf{2 2}$ & RESPONSIBLE PERSON \\
&
\end{tabular}




\section{ABSTRACT}

AUTHOR: $\quad$ Commander Andrew C. Escriva

TITLE: Islamic Fascism: A Real Threat

FORMAT: $\quad$ Strategy Research Project

DATE:

KEY TERMS: $\quad$ Terrorism, Middle East

CLASSIFICATION: Unclassified

The U.S. military is currently engaged in multiple campaigns against non-state entities throughout the world. "Islamic Fascists" are widely recognized as the U.S.'s enemy in the "War on Terror." This project examines the professed ideology of the current jihadist movement as well as historical, philosophical and ideological similarities between the extremists currently engaged in a campaign against western culture and the non-communist authoritarian regimes in Europe prior to and during World War II. The research reveals significant commonality between the movements and may show some insight into the movement's motivations and objectives. 



\section{ISLAMIC FASCISM: A REAL THREAT}

\section{More Than a Buzzword}

Current problem: Islamist extremists are waging war on western culture and like in 1939 we fail to recognize the threat in front of us. The Islamist extremists share historical and ideological ties with previous fascist movements.

It is difficult to "wake-up the west" to understand the threat that is no longer at our doorstep but penetrating our society and way of life with the inculcated intent of either converting or killing us. This sleepwalking is aided by those who dismiss the threat before us.

Addressing the University of Michigan in 2003, film maker Michael Moore opined: "There is no terrorist threat to the United States. Yes there have been horrific acts of terrorism. Yes there will be terrorist acts again. That doesn't mean there is some massive terrorist threat." ${ }^{1}$ In November 2006, United States Central Command's General John Abizaid addressed the Kennedy School of Government at Harvard University with:

We must defeat the extremism of bin Laden and his associated movement. It's murderous. It's ruthless. It's very capable. It's got strength as a network unlike any non-state actor has ever seen before. We've got to defeat it, Think of it as an opportunity to confront Fascism in 1920 if only we'd had the guts to do it then. I believe that if we don't have guts enough to confront this ideology today we will move toward World War Three tomorrow. ${ }^{2}$

Columnist J.D. Henderson rigorously criticized Abizaid and those who liken Al Qaeda and other Islamist extremists to Hitler and ideologically similar fascists of the World War II and prior period. ${ }^{3}$ Henderson's criticism seems similar to those who didn't take seriously the threat of Hitler and his fringe-extremists in the 1920's and considered Winston Churchill a saber-rattling alarmist for criticizing Neville Chamberlain prior to World War II.

Those who dismiss very real threats much the same way the proverbial ostrich dismisses threats from its predators will be referred to as dismissives for this paper.

Spain's former president, Jose Maria Aznar recognizes the long term nature of the threat Islamist extremists pose to western civilization. ${ }^{4}$ His wake up call addressed to Georgetown University in September 2004 received little attention. Aznar references Sun Tzu and implores the west to understand the threat it faces and know its enemy. Part of Aznar's treatise states that in order to succeed in the war against extremists, the west must realize that it is in fact engaged in a war. ${ }^{5}$

In order to contend with a threat, one must first recognize a threat exists, identify it, and then analyze it. 
All other factors being equal, people who fail to recognize that a threat exists are more likely to be vulnerable to it. This vulnerability is what makes dismissive ideology another significant threat to western civilization.

\section{$\underline{\text { Historical Perspective }}$}

\section{German Fascist Beliefs}

The strictest definition of fascism restricts the term's use to just the Italian political party which emerged prior to World War II. ${ }^{6}$ This paper will use a more liberal definition which includes ideologically similar movements including the German Nazi Party of the 1920s, 30s and 40 s.

The German fascists were far more racist than Italian Fascists. ${ }^{7}$ They believed in authoritarianism where the state dominated many facets of society. They displayed many socialist aspects. A common factor of many fascists of various nationalities is their propensity to follow the charismatic leader who puts a face on the movement.

The German fascists sought homogeneity. In addition to internal ethnic, political, and philosophical cleansing in their homeland, they felt dissatisfaction with existing political borders and acted to achieve a union of all Germans in a greater Germany. These fascists desired to keep close hold of the elements of power which directed the course of society and barred nonGermans from influence. ${ }^{8}$ After establishing the Reich, German fascists became less tolerant of diversity and more rigorously persecuted those with divergent characteristics and views.

German Fascists were opportunists who favored action over dogma. Although the Third Reich widely distributed its leader's manifesto, Mien Kampf, many party activists privately admitted to not reading it. ${ }^{9}$

Like current Islamist extremists, the German fascists claimed to elevate women to exalted roles, but relegated women to family roles. They also denounced cultures which held women as sex objects. ${ }^{10}$

Those who sought ideological proliferation focused toward youth. Universities were cultural breeding grounds. ${ }^{11}$ Once in power, the regime started early to indoctrinate children. Youth groups and school curriculums included in ideological education.

Like the Moslem Brotherhood and other radical Islamist movements, people of all social status were represented in the German fascist movement. ${ }^{12}$

Prior to assuming control, fascists were able to intimidate philosophically opposing actors. In addition to attacking culturally heterogeneous segments of society, they also attacked 
divergent philosophy. In May 1933 student demonstrations burned works which they considered "un-German" which were contrary to Fascist ideology. ${ }^{13}$

\section{Fascist Checklist}

Based on his research of traditional fascist movements, Robert Paxton offers a checklist of characteristics common to fascist movements. Across the board, fascist movements tend to:

Sense of overwhelming crisis beyond traditional solutions

Primacy of the group to which one's duties are superior to every right, whether collective or individual and subordination of the individual to it.

Belief that the group is a victim, a sentiment that justifies any action sans moral or legal limits against its enemies internal and external.

Dread of the group's decline under the corrosive effects of individualistic liberalism, class conflict and alien influence.

The need for closer integration of a purer community by consent if possible or by exclusionary violence if necessary.

The need for authority by natural chiefs culminating in a chieftain who is capable of incarnating the group's destiny.

The beauty of violence and the efficacy of will when they are devoted to the group's success.

The right of the chosen people to dominate others without restraint from any kind of human or divine law, right being decided by the sole criterion of the group's prowess within a Darwinian struggle. ${ }^{14}$

Considering the above description of German fascists and Paxton's checklist, subsequent sections of this paper will describe current radical Islamist movements. The similarities between historical fascists and Islamist extremists will show striking similarities.

\section{$\underline{\text { Relationship Between Nazi \& Earlier Islamic Fascists }}$}

Mufti of Palestine

A mufti is an Islamic scholar who is an interpreter or expounder of Islamic law (Sharia), capable of issuing fataawa ${ }^{15}$ (plural of "fatwa" or non-binding legal opinion on Sharia) ${ }^{16}$.

Mohammad Amin al-Husayni was born in Jerusalem and studied Islamic Law at Al-Azhar University in Cairo. ${ }^{17}$ He fled to Syria after the Nebi Musa Riots 04 to 07 April 1920 during which several people were killed and the Jewish Quarter was ransacked. ${ }^{18}$ Among their 
desires, the protesters sought a unified Palestine and Syria. While in Syria, the British authority in Palestine sentenced al-Husayni to prison in absentia for instigating the 1920 Palestine Riots.

In 1921 Herbert Samuel, the British High Commissioner of Palestine replaced the recently deceased Mufti of Palestine with his brother Mohammad Amin al-Husayni naming him the Grand Mufti of Palestine. The Husayni clan held the Mufti of Jerusalem title for many generations. $^{19}$ Overlooking his youth, radical tendencies and incomplete education by pardoning al-Husayni, Samuel made a cultural concession to the local populace. ${ }^{20}$

Husayni had an extensive anti-Semitic and pan-Arab history. He helped organize a society called al-Nadia-al-Arabi, the Arab club, which had anti-Semitic tendencies. ${ }^{21}$ Prior to his Palestinian Nationalist phase, Al-Husayni supported those who would solidify Greater Syria as a Pan-Arab state. ${ }^{22}$

Al-Husayni's early support of pan-Arab nationalism demonstrates that Palestinian Nationalism is a relatively recent phenomena compared to ethnocentrism and anti-Semitism. In 1936, al-Husayni helped found the Arab High Committee, which claimed to seek Arab independence. The committee's activities subsequently morphed into riots and rebellion against British rule in Palestine, and eventually were financed largely by Hitler's Germany. ${ }^{23}$ Husayni et al acted violently to protest British rule and Jewish immigration. Since at least 1937 alHusayni sought a relationship with Hitler's Germany. ${ }^{24}$ In 1937 he visited the German Consul General in Palestine and in 1938, the German fascists started providing greater military and financial supplies to Husayni's Palestinian Arabs.

When the British suppressed the rebellion, Husayni and the other ring leaders fled to exile. The Mufti fled to Haram and then to Lebanon. In 1939 he relocated to Iraq where he enjoyed a high level of influence. In Iraq he stirred pro-Axis sentiments and called for jihad against Britain and her allies. Extremely enthusiastic in his pro-Axis support, Husayni advertised Germany as the savior of the Moslem world and Hitler as a descendant of the Prophet. $^{25}$

King Farouk hosted Italian radio technicians and equipment to relay intelligence to the Axis. $^{26}$

15 April 1941 King Farouk wrote a letter to Hitler seeking cooperation, 30 April, Hitler responded in a supportive manner and requested a confidential, trusted agent whom they agreed would be the Mufti. ${ }^{27}$

In 1941 al-Husayni issued a fatwa calling for Muslims to join in jihad against "British aggression" which targeted the Muslim world. He then went to Germany where Hitler officially received him. Al-Husayni spent the rest of the war with his allies working as a propagandist and 
recruiter. In 1943 he went to the Balkans to recruit Bosnian Muslims and raised divisions of Waffen SS and other types of army. ${ }^{28}$ He also established schools to indoctrinate imams and mullahs that would accompany Muslim soldiers fighting with the Germans. ${ }^{29}$

After the war, al-Husayni was somewhat transient and eventually ended up in Egypt with asylum.

In 1948, al-Husayni, while living in Syria, was instrumental in coordinating troops to fight Zionists in Palestine and to train the Syrian army. These forces included Bosnian Muslims who had become stateless after World War II and fugitive German soldiers. ${ }^{30}$

Al-Husayni's political and military influence waned somewhat between the 1948 Palestine War and his death in Lebanon in 1974 but his followers include Yasser Arafat among others.

The Moslem Brotherhood shared a great deal with the Grand Mufti. It believed in fundamental Islam and appreciated German Fascist ideology. When Marouf Dawalibi, chieftain of the Syrian Moslem Brotherhood orchestrated al-Husayni's escape from France and possible prosecution for war crimes in 1946 , he cemented their relationship. ${ }^{31}$

\section{Moslem Brotherhood}

The Moslem Brotherhood slogan became "Allah is our goal; the Messenger is our model; the Koran is our constitution; jihad is our means; and martyrdom in the way of Allah is our aspiration." ${ }^{32}$ Variations in translation also yield: "Allah is our goal, Mohammed our leader, the Koran our law, Jihad our path, death in the service of Allah our command". ${ }^{33}$ Or "The Quran is our constitution. The prophet is our guide; and martyrdom for Allah is our greatest ambition" ${ }^{34}$

In 1928 Hassan al-Banna founded the Moslem Brotherhood. The society was a theological, political, and social organization that sought an Islamic society based on Wahhabist ideology. ${ }^{35}$ The Brotherhood's stated objectives are building the Muslim individual, and family;, as well as building Muslim society, the Muslim state and a Khilafa or union of Muslim states. ${ }^{36}$ Eventually the Brotherhood focused mostly on the political aspects of freeing the Muslim homeland of European colonialism and establishing a unified Islamic State or Caliphate. ${ }^{37}$ Other facets of the Brotherhood included a network of underground cells, who secretly bought weapons, trained fighters, formed underground assassination squads, founded sleeper cells of subversive supporters in the ranks of the army and police. ${ }^{38}$

Hassan al-Banna articulated his vision with: "We want an Arabian United States with a caliphate at its head and every Arab state subscribing wholeheartedly to the Koran. We must return to the Koran, which preaches the good life, which forbids us to take bribes, to cheat, to kill 
one's brother. The laws of the Koran are suitable for all men at all times until the end of the world. This is the day and this is the time that the world needs Islam most." 39

When World War II started, al-Banna solicited assistance from both Germany and Italy and during WWII al-Banna admired and allied himself with Hitler. ${ }^{40}$ Like al-Husayni the Grand Mufti of Palestine, these Arab extremists approved of the anti-Semitic and authoritarian aspects of Nazi fascism. Al-Banna's movement even shared intelligence with the Germans during the war. $^{41}$

Saleh Harb Pasha, Egypt's former minister of defense, leader of Young Muslim Association, member of the Arab League, and associate of al-Banna clearly favored German Fascist ideology when he said: "If Rommel had won, we would be independent now. If the Nazis and Fascists had won, they would have been friends to the whole Arab world. There would be no Zionist problem because there would be no Zionist Jews... or any Jews at all left." ${ }^{24}$ Aboul Saud, an academic at al Anzar University encourages observors to draw parallels between Islamic Fascism and other varieties of fascism with his statement: "You might describe Mohammedanism as a religious form of state socialism. The Koran gives the state the right to nationalize industry, distribute land, or expropriate property. It grants the ruler of the state unlimited powers, so long as he does not go against the Koran. The Koran is our personal as well as our political constitution." ${ }^{43}$ Saud's use of the term state socialism seems very similar to national socialism, or Nazism.

\section{$\underline{\text { Stated Jihadist Ideologies }}$}

The Brotherhood: Philosophical Precursor to Al Qaeda.

Convinced of the Brotherhood's role in the assassination of Prime Minister Mahmud Nuqruashi government operatives assassinated al-Banna in 1949. ${ }^{44}$

Sayid Qutb was an educator who was pursuing graduate work in the United States when al-Banna died. Prior to his American experience, Qutb was fairly progressive. Something about living and studying in the United States convinced him of the un-Islamic nature of the United States and helped turn him to radical Islam. ${ }^{45}$ When he returned to Egypt, Qutb became active in the Brotherhood, eventually rising to prominence in the movement. ${ }^{46}$

Qutb was a prolific writer whose teachings are still in use among Islamist radicals. In 1965, the Egyptian government jailed Qutb along with thousands of Brotherhood members. Nasser's government hanged Qutb along with a few other primary conspirators and eventually released most of the rest of the imprisoned members. 


\section{Zawahiri}

Ayman al-Zawahiri was born to a prominent Egyptian family in 1951. His father was a professor at a prestigious medical school and his Great Uncle was the highly revered Grand Imam of Al-Azhar University. ${ }^{47}$ He joined the Brotherhood as a teenager and in addition to his activity in the Islamist underground, he was convicted and jailed in conjunction with Sadat's assassination. Zawahiri experienced a catharsis in prison which prompted him to adopt more violent tendencies. Some apologists claim his change to more violent methodology resulted from the Egyptian's harsh treatment including torture. Another theory holds that he spent a great deal of time with violent extremist fellow prisoners. ${ }^{48}$ Relatively moderate Muslims have a different perspective than do westerners. Zawahiri was convicted and jailed for storing weapons and explosives for the cells that assassinated Anwar Sadat. A long time family friend considered joining an underground group and facilitating terrorist attacks to be moderate because Zawahiri did not actually detonate bombs or fire weapons himself. ${ }^{49}$

As a physician and long term philosophical Islamist, he migrated to Pakistan to provide aide during Soviet-Afghan War. While enjoying United States support, he recognized that the United States only supported the mujahideen as a proxy against the Soviet Union. He considered the Soviet invasion as a more immediate threat to the Muslim world but the United States was just as evil and he planned to deal with it after defeating the Soviets. ${ }^{50}$

Al-Zawahiri met a fellow mujahideen named Usama bin Laden during the Soviet conflict. Although al-Zawahiri helped found Islamic Jihad to fight the Soviets, victory brought a new focus. In 1989, bin Laden founded Al Qaeda, in English: The Base. ${ }^{51}$ It merged with alZawahiri's group and became an international network of Islamists seeking to rid Muslim lands of non-Muslim influence. ${ }^{52}$

Usama bin Laden

Usama bin Laden was a Saudi Arabian citizen born to a fabulously wealthy, politically connected family. While working towards his degree in economics and public administration at King Abdul Aziz University in Jeddah Saudi Arabia, he became involved with the Moslem Brotherhood. ${ }^{53}$ Bin Laden had gained experience with demolitions while working with the family business. In the early 1980's, he started making trips to Afghanistan and brought hundreds of tons of heavy construction equipment to support mujahideen efforts. He sponsored many projects including the construction of tunnels, roads and rudimentary hospitals. ${ }^{54}$ Eventually, bin Laden became more involved in operational matters and attained a degree of celebrity. As 
mentioned, after the mujahideen defeated the Soviets, bin Laden formed Al Qaeda and changed his focus from liberating Afghanistan to fomenting animosity towards the United States.

Usama bin Laden's jihad movement seems to be motivated by grievances. He reiterates three substantive grievances and three grievances of principal ${ }^{55}$. Professor John Jandora states the substantive grievances include: United States troop presence close to Mecca and Medina in Saudi Arabia; Israeli aggression in Palestine and a western conspiracy with unfavored mid-eastern governments to undervalue oil. The principals he considers to be at odds with the west are anti-materialism, anti-elitism, and anti-civic. ${ }^{56}$ All three of these principals can be tied back to his belief in Shari'ah's or Islamic law's supremacy over any legal, political, or social system devised by man.

Although he is completely devoid of theological credentials, bin Laden's fatwas recount more than a thousand years of history and animosity against all people who are not Muslim. ${ }^{57}$ Bin Laden claims that his major grievance with the United States is western presence in Muslim lands, "The land of the two holy places" in particular. ${ }^{58} \mathrm{He}$ also bears great animosity towards the Saudi government because its alliance with the United States and in his opinion its abandoning Shari'ah. ${ }^{59}$

After belief, there is no duty more important than pushing the American enemy out of the holy land. ${ }^{60}$ Bin Laden considers any United States citizens to be legitimate targets. Even if people are not in the military or other government service, he believes that if they pay taxes or contribute to the United States economy in any way, or support the troops or government, they are adding to the United States' war making ability. He puts his own spin on proportionality and discrimination.

In 2004, the Jordanian terrorist Abu Mus'ab al-Zarqawi pledged fealty to bin Laden and Al Qaeda. $^{61}$ Zarqawi's "Al Qaeda of the Two Rivers" (Iraq) actively targeted Shia as well as United States assets in Iraq. Bin Laden proclaimed: "If it is not possible to push back the enemy except by the collective movement of the Muslim people, then there is a duty on the Muslims to ignore the minor differences among themselves." ${ }^{62}$ By ignoring bin Laden's directive, Zarqawi demonstrated the opportunistic nature of a large portion of the radical Islamist movement, that is picking and choosing only which portions of theology and doctrine that support its secular desires; and the extremely narrow focus of their thinking in that any Muslims who do not completely agree with all facets of their ideology have voided their Islamic status. 
What the Quran Says

The Quran requires Muslim warriors to "Fight in the way of Allah." Among the tenants, this mandate calls for proportionality, target discrimination, humane treatment of noncombatants, and not instigating wars of aggression. ${ }^{63}$ Aside from passages encouraging victorious Muslims to ransom prisoners, nothing in the Quran specifically prescribes or proscribes harassing, torturing, or executing prisoners. ${ }^{64}$

Islamic Extremists approach theological doctrine the way we (United States military) approach military doctrine. They selectively employ the parts which fit the way they see conducting operations without having read it or understood the concepts ahead of time. ${ }^{65}$ Islamic fascists conveniently interpret the Quran's prohibiting offensive war and maltreatment of non-combatants by defining persecution and combatants and non-combatants in ways which suit their agenda and methodology.

Al Qaeda sympathizer Sheikh Ali Bin Khodair Al-Khodhari issued a fatwa which defined all Americans as combatants using the rational that if individuals were not serving in the military, they would participate in the economy and add to the United States' economic and military might. If that was not the case, Americans still failed to oppose the United States government and its policies thereby forfeiting their status as non-combatants. ${ }^{66}$

\section{$\underline{\text { The Caliphate }}$}

\section{Actual}

The historical Caliphate was an Islamic empire which spread from Spain to India. At its high water mark, the Caliphate also dominated half of France and parts of Italy. The Spaniards finally rolled the Caliphate out of Spain in 1492 and the end of World War I also brought the end of the Caliphate's remnants, the Ottoman Empire.

As Described by Jihadist

Jihadi propagandists hold the Caliphate as a mystical golden age to which they want to return. Society, politics, and theology are rolled into one entity under the form of Islam espoused by the particular Jihadi. Jordanian Journalist Fouad Hussein details what he claims to be a long term Al Qaeda strategy in his relatively concise seven steps to a Caliphate.

The First Phase Known as "the awakening" -- this has already been carried out and was supposed to have lasted from 2000 to 2003 , or more precisely from the terrorist attacks of September 11, 2001 in New York and Washington to the fall of Baghdad in 2003. The aim of the attacks of 9/11 was to provoke the US into declaring war on the Islamic world and thereby "awakening" Muslims. "The first phase was judged by the strategists and masterminds behind al-Qaida as very 
successful," writes Hussein. "The battle field was opened up and the Americans and their allies became a closer and easier target." The terrorist network is also reported as being satisfied that its message can now be heard "everywhere."

The Second Phase "Opening Eyes" is, according to Hussein's definition, the period we are now in and should last until 2006. Hussein says the terrorists hope to make the western conspiracy aware of the "Islamic community." Hussein believes this is a phase in which al-Qaida wants an organization to develop into a movement. The network is banking on recruiting young men during this period. Iraq should become the center for all global operations, with an "army" set up there and bases established in other Arabic states.

The Third Phase This is described as "Arising and Standing Up" and should last from 2007 to 2010. "There will be a focus on Syria," prophesies Hussein, based on what his sources told him. The fighting cadres are supposedly already prepared and some are in Iraq. Attacks on Turkey and -- even more explosive -in Israel are predicted. Al-Qaida's masterminds hope that attacks on Israel will help the terrorist group become a recognized organization. The author also believes that countries neighboring Iraq, such as Jordan, are also in danger.

The Fourth Phase Between 2010 and 2013, Hussein writes that al-Qaida will aim to bring about the collapse of the hated Arabic governments. The estimate is that "the creeping loss of the regimes' power will lead to a steady growth in strength within al-Qaida." At the same time attacks will be carried out against oil suppliers and the US economy will be targeted using cyber terrorism.

The Fifth Phase This will be the point at which an Islamic state, or caliphate, can be declared. The plan is that by this time, between 2013 and 2016, Western influence in the Islamic world will be so reduced and Israel weakened so much, that resistance will not be feared. Al-Qaida hopes that by then the Islamic state will be able to bring about a new world order.

The Sixth Phase Hussein believes that from 2016 onwards there will a period of "total confrontation." As soon as the caliphate has been declared the "Islamic army" it will instigate the "fight between the believers and the non-believers" which has so often been predicted by Osama bin Laden.

The Seventh Phase This final stage is described as "definitive victory." Hussein writes that in the terrorists' eyes, because the rest of the world will be so beaten down by the "one-and-a-half billion Muslims," the caliphate will undoubtedly succeed. This phase should be completed by 2020, although the war shouldn't last longer than two years. ${ }^{67}$

In 2005, Swiss journalist Sylvain Besson published La Conquête de l'Occident: Le Projet Secret des Islamistes or Conquering the West: The Islamists' Secret Project. Besson's book is based on a 1982 dated document that Swiss authorities seized which allegedly detailed the Moslem Brotherhoods strategy to establish a global Caliphate.

Both Al Qaeda and the Moslem Brotherhood have articulated grand strategies which target democracy and western values. 


\section{$\underline{\text { All Muslims are not Jihadists }}$}

\section{Define Jihad}

The Arabic word jihad's literal translation is struggle. Many Muslims consider jihad to be an internal struggle to become a better person and more completely embrace the will of God and the tenants of the religion.

The literal translation of Mien Kampf, Adolf Hitler's manifesto, is "My Struggle." Another interpretation of jihad, more specifically jihad bis saif or jihad of the sword, is Holy War or Harb al moqadasa. There are two varieties of jihad bis saif: war in defense of Muslim lands (protect the house of peace or Dar al Islam) and conquer the non-Muslim world (the house of war or Dar al Harb.) for Allah. ${ }^{68}$ Harabah is the Arabic word for war of intimidation. Some consider harabah to better describe radical Islamists' efforts against the west than jihad. The media's, including Arab language and western television, use of jihad rather than harabah may lend legitimacy to radical Islamist efforts in the eyes of more moderate sections of the Islamic world.

\section{What's Going on}

Most Muslim people do not advocate violent extremist ideology. Some experts estimate the world's Muslim population at approximately one billion, two hundred million people. These same experts estimate the percentage that is sympathetic to Muslim extremists at around ten to fifteen percent, which is still a very large number. They believe the percentage of Muslims who don't actively espouse extremist ideology but hold anti-American and anti-Zionist beliefs to be significantly higher. ${ }^{69}$

The 2006 Pew Global Attitude Survey shows that average citizens in predominantly Muslim countries have a perspective very different from the west. Overwhelmingly, they attribute negative characteristics to westerners at much higher percentages than do Muslims living in western countries. The percentage of negative perceptions held by Muslims living in predominantly Muslim countries dwarfs the percentage of negative perceptions that westerners hold of Muslims. ${ }^{70}$ This phenomenon could be the result of steady diet of propaganda and imbalanced media. One possible conclusion is that the extremists are wining the information campaign and are shifting the definition of moderate towards an extreme view. This difference in perception of cultures makes it difficult to universally apply a definition of extremist.

Factors other than definitions make it difficult to identify extremists. A universal greeting within the Arab world is: "Salaam alekieum", or in English: "Peace be upon you." Verse 25:63 of the Quran says "The faithful slaves of the Beneficent One are they who walk upon the earth modestly and when the foolish ones address them, answer "Peace."'71 Another translation 
yields "The true followers of the Benevolent are those who walk the earth in humility and when the ignorant address them, say "Peace"'. ${ }^{72}$ Or "The true servants of the Merciful are those who walk humbly on the earth and when ignorant people behave insolently towards them, say "Peace to you."'”73 People other than Islamist extremists must differentiate between people who use the traditional greeting genuinely, and those who use it as part of an information operation. The three translations show varying degrees of hostility to non-believers.

Many extremists claim to be moderate. Anjem Chouday al-Muhajiroun, head of the London's Society of Muslim Lawyers, claimed to be the first to condemn the September 11 terrorist attacks as illegitimate during western media coverage. Yet to a predominantly Muslim audience he lauded the "magnificent nineteen." ${ }^{\text {"74 }}$ The deceptive nature of some extremists makes identifying and appropriately dealing with them more challenging.

Abd al Hamid al Ansari, former dean of the Islamic Law School at University of Qatar considers media content which advocates hate and violence to encourage extremism and violence in those who view it and recognizes the prevalence of hateful content in Arab language satellite television news. ${ }^{75}$ If these broadcasts are the predominant news source many people, al Ansari's statement lends credence to the theory of perspectives shifting towards the extreme.

Access to television, radio, and cheap paperback versions of the Quran in numerous languages contribute to fragmenting religious authority. The meaning of scripture no longer needs to be interpreted by religious authorities but lies in the eye of the beholder. With direct access, many Muslims do not feel compelled to defer to religious scholars. ${ }^{76}$

Many Muslims do not speak Arabic and some Muslim populations experience low literacy rates. Islamic scholars have translated the Quran into many languages. Some current scholars of Islam estimate that many Muslims are only minimally familiar with specific verses of the Quran. They only memorized enough Arabic to recite the obligatory daily prayers and do not understand the meanings of the Arabic words. ${ }^{77}$

Between the possible subtleties in translation and a large number of illiterate people relying on an oral rendition, diverse interpretations of the Quran and Haddiths exist.

The diverse interpretations coupled with the absence of a universally accepted religious authority make it easier for radicals to claim legitimacy while ignoring historical and literary context. Radical Islamists exploit fragmented religious authority to justify their actions and wrap themselves in a theological flag. These opportunists literally interpret select passages of the Quran to justify their actions and recruit and manipulate others. ${ }^{78}$ 
In summary, the absence of universal definitions of moderate and extremist, a shifting perspective resulting from slanted media and the propagation of fragmented religious authority enable what the west considers to be extremist to gain legitimacy in the Muslim world.

Nazi Ideology Matches Islamist Fascist Ideology.

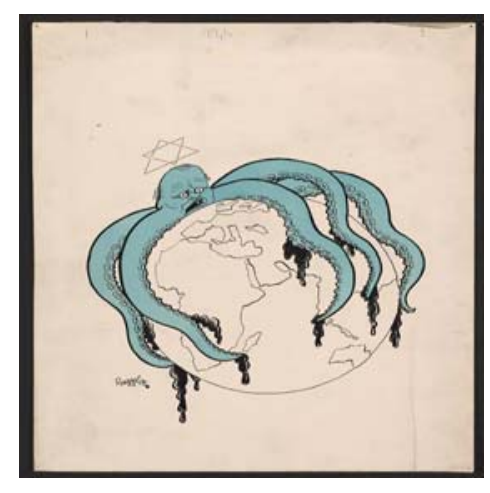

Figure 1: 1938 Germany $^{79}$

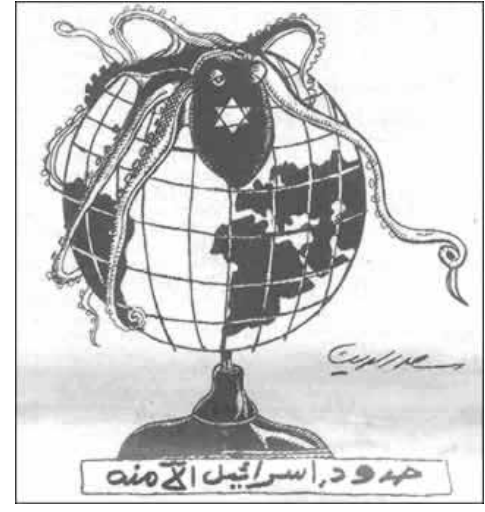

Figure 2: 2002 Egypt $^{80}$

Observers can draw numerous parallels between the German fascist movement and those of the radical Islamists in both ideology and actions. Figures 1 and 2 may have been drawn sixty eight years apart but both result from similar ideology. The principal difference between Islamic Fascists and those fascists many consider more traditional is that Islamic Fascists are not reacting to a malfunctioning democracy in their homeland. ${ }^{81}$ The German fascist practice of relegating heterogeneous elements of society to second class status parrots the Quranic axiom that allowed non-Muslim people of the book to exist in Muslim society as long as they paid additional taxes and accepted their subservient role. The concept of a greater Germany seems analogous to Pan-Arabism. The previously mentioned German fascists who hadn't read their leader's manifesto and were unfamiliar with their movement's doctrine seem similar to the Muslims who haven't read much of the Quran mentioned earlier. On September 30, 2005, the Danish newspaper Morgenavisen Jyllands-Posten published a series of political 
cartoons which satirized radical Islamists. In October 2005, violent demonstrations erupted across the Muslim world including Islamic enclaves in western cities. ${ }^{82}$ The 2005 protests of the Danish cartoons seem reminiscent of the 1933 demonstrations against "un-German" art and literature.

Today's fascists pose an even greater threat than those of a bygone era because they enjoy a significantly larger population and have access to great resources. Another advantage Islamist extremists have over the German fascists is their basic motivation. The German fascists appealed to nationalism. Today's Islamic fascists claim to be on a divinely inspired mission which mandates all believers to participate.

\section{Conclusion}

Islamist fascists do not present a monolithic threat. If western civilization ignores the growing threat, it will only increase its capability and popular support. Islamic fascists' history and ideology are intertwined with the fascists who plunged the globe into World War II. Islamic fascists are at least as committed to defeating western democracy. Many of today's radical Islamists can trace their movements' ideology back to al-Banna and al-Husayni and their affinity for German fascists. One of the biggest variables is the world's roughly one billion person Muslim population which has not committed to extremism or western type democracy. Which ever movement obtains their support will possess a huge advantage in this conflict. Islamic fascists' threat is real and if western civilization is to succeed, it must recognize the threat's existence and take action to survive.

\section{Endnotes}

${ }^{1}$ Peter Meier, producer, Obsession: Radical Islam's War Against the West , 2006 DVD

2 John Abizaid available from http://ioforum.harvard.edu:8080/ramgen/ fr20061117abizaid.rm accessed on 12 Dec 2006

3 J.D. Henderson "Officers Need Good Judgment" available from http://www.inteldump.com/posts/1164070286.shtml accessed on 17 Dec 2006.

${ }^{4}$ Jose Maria Aznar "Seven Thesis on Today's Terrorism" (Washington DC: Georgetown University, 21 Sep 2004), available from http://www3.georgetown.edu/president/aznar/ inauguraladdress.html accessed on 29 Aug 2006

\footnotetext{
${ }^{5}$ Aznar

${ }^{6}$ Michael Mann Fascists. Cambridge University Press, Cambridge UK 2004, 5.
} 
${ }^{7}$ Mann, 139.

${ }^{8}$ Mann, 151.

${ }^{9}$ Mann, 141.

${ }^{10}$ Mann, 148.

${ }^{11}$ Mann, 152.

12 Mann, 171.

${ }^{13}$ George Blum The Rise of Fascism in Europe. Greenwood Press Westport CT 1998, 43.

${ }^{14}$ Robert Paxton Anatomy of Fascism. (New York, NY: Albert A. Knopf, 2004), 220.

${ }^{15}$ http://en.wikipedia.org/wiki/Mufti accessed 11 Dec 2006

${ }^{16}$ Phillip Mattar Mufti of Jerusalem (New York, NY: Columbia Press, 1988), 3.

${ }^{17}$ Mattar, 8.

18 John McTague "The British Military Administration in Palestine 1917 to 1920" Journal of Palestine Studies 1978 University of California Press Berkeley, CA available from http://www.jstor.org/view/0377919x/di009588/00p0005b/12?frame=noframe\&userid= 9063080a@carlisle.army.mil/01cc99331600501b512bf\&dpi=3\&config=jstor accessed 09 Jan 07

${ }^{19}$ Mattar, 6.

${ }^{20}$ Mattar, 19.

${ }^{21}$ Mattar, 11.

22 Mattar, 12.

23 John Roy Carlson, Cairo to Damascus (New York, NY: Alfred A. Kopf, 1951), 92.

${ }^{24}$ Mattar, 101.

${ }^{25}$ Carlson, 416.

${ }^{26}$ Carlson, 111.

${ }^{27}$ Carlson,112.

${ }^{28}$ Carlson, 423.

${ }^{29}$ Carl Savich, "Islam Under the Swastika" 2001, available from http://www.rastko.org.yu/ rastko-bl/istorija/kcsavic/csavich-islam_e.html, accessed on 19 Feb 2007.

${ }^{30}$ Carlson, 408. 
${ }^{31}$ Carlson, 411.

${ }^{32}$ Noreen S. Ahmed-Ullah, Sam Roe and Laurie Cohen A rare look at secretive Brotherhood in America. http://www.chicagotribune.com/news/local/chi0409190261sep19,1,3947993.story?coll=chi-news-hed\&ctrack=1\&cset=true

${ }^{33}$ Ron Leshem and Amit Cohen "Islamic Terror: A History of the Moslem Brotherhood" Available from http://www.jdl.org/enemies/islam/muslim_brotherhood.shtml accessed 17 Dec 2006.

${ }^{34}$ T.P. Schwartz-Barcott, War Terror \& Peace in the Qu'ran and in Islam: Insights for Military \& Government Leaders. (Carlisle, PA: Army War College FoundationPress, 2004), 3.

${ }^{35}$ Adam Parfey, ed. Extreme Islam: Anti-American Propaganda of Muslim Fundamentalism. (Los Angeles, CA: Feral House, 2001) 75.

${ }^{36}$ Parfey, 76.

${ }^{37}$ Marc Erikson, "Islamism, Fascism and Terrorism" Asia Times Online 05 Nov 2002 available from http://www.atimes.com /atimes/Middle_East/DK08Ak03.html accessed 03 Jan 2007.

${ }^{38}$ Carlson, 97?

${ }^{39}$ Carlson, 92.

${ }^{40}$ Leshem and Cohen.

${ }^{41}$ Leshem \& Cohen.

${ }^{42}$ Carlson, 110.

${ }^{43}$ Carlson, 117.

${ }^{44}$ Ahmed-Ullah, Roe \& Cohen

${ }^{45}$ Robert Siegel, "Sayyid Qutb's America" (NPR All Things Considered, 6 May 2003) Available from http://www.npr.org/templates/story/story.php?storyld=1253796, accessed on 20 Feb 2007.

${ }^{46}$ Zafar Bangash, "Remembering Sayyid Qutb, an Islamic Intellectual and Leader of Rare Insight and Integrity." (Muslim Media, 1 Sep 1999) Available from http://www.youngmuslims.ca /online_library/books/ milestones/remember.asp, accessed on 20 February 2007.

${ }^{47}$ Lawrence Wright, "The Man Behind Bin Laden" (The New Yorker online, 16 Sep 2002) Available from: http://www.mafhoum.com/press6/175C33.htm accessed 18 Dec 2006.

\footnotetext{
${ }^{48}$ Wright.

${ }^{49}$ Wright.
} 
${ }^{50}$ Wright.

${ }^{51}$ Peter Bergen, Holy War Inc: Inside the Secret World of Osama bin Laden, (New York, NY: Free Press, 2001), 58.

52 John Pike "Al-Qa'ida (The Base)." (Federation of American Scientists, 12 Oct 2005) Available from http://www.fas.org/irp/world/para/ladin.htm. Accessed on 20 Feb 2005.

${ }^{53}$ Bergen, 47.

${ }^{54}$ Bergen, 50.

55 John Jandora Osama bin Laden's Global Jihad Myth and Movement. Military Review, November-December 2006 page 42.

${ }^{56}$ Jandora, 43.

${ }^{57}$ Bergen, 78.

${ }^{58}$ Usama Bin Laden, 1996 Fatwa available from http://www.pbs.org/newshour/terrorism/ international/fatwa_1996.html accessed 07 Nov 2006.

${ }^{59}$ Bin Laden.

${ }^{60}$ Bin Laden.

${ }^{61}$ Abu Mus'ab al-Zarqawi, Letter to Usama bin Laden 04022004 available from http://www.globalsecurity.org/military/world/para/zarqawi.htm accessed 11 Dec 2006.

${ }^{62}$ Bin Laden.

${ }^{63}$ Schwartz-Barcott, 47.

${ }^{64}$ Schwartz-Barcott, 77.

65 James Embrey, email message to author 13 Feb 2007.

${ }^{66}$ Jawad Hashim, Shakir Al-Nabulsi, Lafir Lakhdar, Letter to UN Security Council 8 Nov 2004 available from http://www.memri.org/bin/articles.cgi?Area=sd\&ID=SP81204 accessed 17 Dec 2006.

67 Yassin Musharbash, "What Al Qaeda Really Wants" available from http://www.spiegel.de/international/0,1518,369448,00.html accessed 03 Jan 2007.

68 Schwartz-Barcott 149.

${ }^{69}$ Meier.

${ }^{70}$ Pew Global Attitudes Project, Pew Research Center 22 Jun 2006

${ }^{71}$ Schwartz-Barcott, 43. 
72 The Quran. (Al-Madina, KSA: King Fahd Holy Quran Printing Complex, 1411H) 1051

${ }^{73}$ Syed Abula a la Maududi, trans. The Holy Qur'an. (Lahore, Pakistan: Islamic Publications, 2000), 581.

${ }^{74}$ Meier.

${ }^{75}$ Meier.

${ }^{76}$ Schwartz-Barcott, 9.

${ }^{77}$ Schwartz-Barcott, 25.

${ }^{78}$ Schwartz-Barcott, 10.

79 Josef Plank, circa 1938, available from http://fcit.usf.edu/holocaust/arts/PROPAGAN/ octopus.JPG accessed 18 Jan 2007.

${ }^{80}$ Al Ahram 25 May 2002. Available from http://www.intelligence.org.il/eng/sib/ 4_04/as_egypt.htm accessed 18 Jan 2007

${ }^{81}$ Paxton, 204.

${ }^{82}$ Carsten Juste, "Honourable Fellow Citizens of the Muslim World", Morgenavisen Jyllands-Posten, 30 Jan 2006, available from http://www.jp.dk/meninger/ncartikel:aid=3527646 accessed on 12 Feb 2007. 